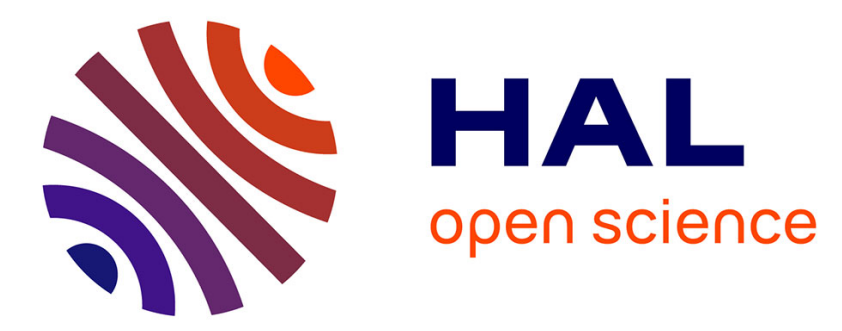

\title{
Compounds based on octahedral B6 units: hexaborides and tetraborides
}

Jean Etourneau, Jean-Pierre Mercurio, Paul Hagenmuller

\section{To cite this version:}

Jean Etourneau, Jean-Pierre Mercurio, Paul Hagenmuller. Compounds based on octahedral B6 units : hexaborides and tetraborides. Vlado I. Matkovich. Boron and refractory borides, Springer, pp.115137, 1977, ISBN 3-540-08181-X. hal-00132532

\section{HAL Id: hal-00132532 \\ https://hal.science/hal-00132532}

Submitted on 11 Jan 2022

HAL is a multi-disciplinary open access archive for the deposit and dissemination of scientific research documents, whether they are published or not. The documents may come from teaching and research institutions in France or abroad, or from public or private research centers.
L'archive ouverte pluridisciplinaire HAL, est destinée au dépôt et à la diffusion de documents scientifiques de niveau recherche, publiés ou non, émanant des établissements d'enseignement et de recherche français ou étrangers, des laboratoires publics ou privés. 


\title{
Compounds Based on Octahedral $\mathrm{B}_{6}$ Units: Hexaborides and Tetraborides
}

\author{
J. Etourneau, J.-P. Mercurio, and P. Hagenmuller
}

Atoms in a three-dimensional boron lattice have a five-fold coordination when situated in the vertex positions of a $B_{6}$ octahedron: they share four bonds with atoms of the same octahedron and the fifth one points outwards along one of the $\mathrm{A}_{4}$ axes of the octahedron. The presence uf this fifth bond is responsible for the occurrence of the threedimensional structure. Only two families of boron-rich borides have structures based on the $B_{6}$ octahedron: the $\mathrm{CaB}_{6}$-type hexaborides and the $\mathrm{ThB}_{4}$-type tetraborides.

MOISSAN and WILLIAMS (1897) reported the discovery of CaB 6 -type cubic hexaborides. Later ANDRIEUX (1929) proposed a general synthesis method for these compounds, by fused-salt electrolysis. Then Von STACKELBERG and NEUMANN (1932) determined the approximate structure, which was later refined (ALLARD, 1932; PAULING and WEINBAUM, 1934; BLUM and BERTAUT, 1954).

Fused salt electrolysis had also allowed ANDRIEUX (1929) to prepare $\mathrm{UB}_{4}$ uranium tetraboride. Later BREWER and SAWYER (1950) prepared CeB 4 , $\mathrm{ThB}_{4}$ and $\mathrm{UB}_{4}$ isotypes; BERTAUT and BLUM (1949) fixed the positions of the metal atoms in the $\mathrm{UB}_{4}$ lattice. ZALKIN and TEMPLETON (1950) established a complete model of the crystal structure using a $\mathrm{ThB}_{4}$ single crystal.

\section{Crystal structure}

\section{a) $\mathrm{CaB}_{6}-$ Type Hexaborides}

Elements that form hexaborides of a $\mathrm{CaB}_{6}$-type are potassium, alkaline earths, yttrium and the larger lanthanides, as well as thorium and some actinides (NASLAIN and ETOURNEAU, 1966; EICK and MULFORD, 1969; MCDONALD and STUART, 1960). The crystal structure of these compounds with cubic symmetry $\left(\mathrm{Pm} 3 \mathrm{~m}, \mathrm{O}_{\mathrm{h}}\right)$ is represented in Figure 1. It is characterized by a three-dimensional skeleton of $B_{6}$ boron octahedra, the interstices of which are filled by metal atoms.

Theoretical studies have shown that in the absence of an inserted metal the covalent boron sublattice is electron-deficient, and that electron transfer from the metal sublattice to that of boron is required (EBERHARDT et al., 1954; LIPSCOMB and BRITTON, 1960). The existence of thermodynamically stable $\mathrm{KB}_{6}, \mathrm{Na}_{x} \mathrm{Th}_{\mathrm{I}-\mathrm{x}_{6}} \mathrm{~B}_{6}$ and $\mathrm{Na}_{x} \mathrm{Ba}_{I-x} \mathrm{~B}_{6}$ phase indicates that the number of tranferred electrons is a least 1 (BLUM and BERTAUT, 1954; NASLAIN and ETOURNEAJ, 1966).

According to diffexent investigators, the structural parameters differ quite noticeably, which suggests the existence of homogeneity ranges. Many studies have been undertaken concerning the non-stoichiometry of $\mathrm{MB}_{6}$ hexaborides: all of them lead to deviations from stoichiometry through cation defects. The reported results are summed up in Table 1. 


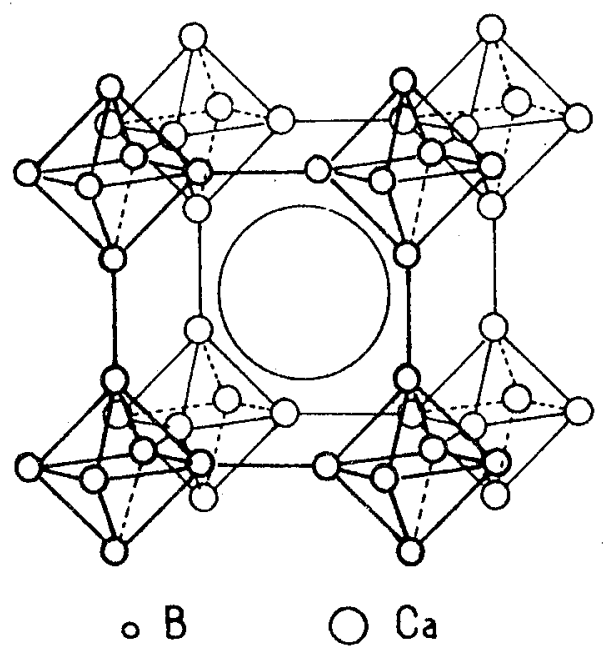

Fig. 1. Structure of $\mathrm{CaB}_{6}$

Table 1.

\begin{tabular}{|c|c|c|c|}
\hline $\mathbf{M}$ & $\mathbf{x}$ & Parameters $(\stackrel{3}{A})$ & Reference \\
\hline $\mathrm{K}$ & $1 . \infty$ & 4.232 & NASLAIN and ETOURNEAU (1966) \\
\hline $\mathrm{Ca}$ & 1.00 & 4.1520 & ETOURNEAU $(1970)$ \\
\hline $\operatorname{sr}$ & $1 . \infty$ & 4.1981 & ETOURNEAU $(1970)$ \\
\hline $\mathrm{Ba}$ & $1 . \infty$ & 4.2706 & JOHNSON and DAANE (1961) \\
\hline $\mathrm{Y}$ & 1.00 & 4.103 & JOHNSON and DAANE (1961) \\
\hline La & 1.00 & 4.1561 & JOHNSON and DAANE (1961) \\
\hline La & 0.77 & 4.1561 & JOHNSON and DAANE (1961) \\
\hline $\mathrm{Ce}$ & $\begin{array}{l}1.00 \\
0.70\end{array}$ & $\begin{array}{l}4.1396 \\
4.1414\end{array}$ & YAJIMA and NIIHARA (1971) \\
\hline Pr & $\begin{array}{l}1.00 \\
0.69\end{array}$ & $\begin{array}{l}4.1329 \\
4.1355\end{array}$ & YAJIMA and NIIHARA (1971) \\
\hline Nd & $1 . \infty$ & 4.1265 & MERCURIO (1974) \\
\hline $\operatorname{Sm}$ & $\begin{array}{l}1.00 \\
0.68\end{array}$ & $\begin{array}{l}4.1304 \\
4.1278\end{array}$ & NIIHARA (1971) \\
\hline Eu & $\begin{array}{l}1.00 \\
0.90\end{array}$ & $\begin{array}{l}4.1780 \\
4.1843\end{array}$ & SCHWETZ and LIPP (1973) \\
\hline Gd & $\begin{array}{l}1.00 \\
0.70\end{array}$ & $\begin{array}{l}4.1065 \\
4.1113\end{array}$ & YAJIMA and NIIHARA (1971) \\
\hline $\mathrm{Tb}$ & $\begin{array}{l}1.00 \\
0.75\end{array}$ & $\begin{array}{l}4.1008 \\
4.1052\end{array}$ & YAJIMA and NIIHARA (1971) \\
\hline Dy & 1.00 & $\begin{array}{l}4.0969 \\
4.1008\end{array}$ & SPSAR (1974) \\
\hline $\mathrm{Yb}$ & 1.00 & 4.1478 & ETOURNEAU et al. (1970) \\
\hline Th & $\begin{array}{l}1.00 \\
0.78\end{array}$ & $\begin{array}{l}4.1104 \\
4.1125\end{array}$ & ETOURNEAU et al. (1971) \\
\hline $\mathrm{Np}$ & - & 4.1129 & EICK and MULFORD (1969) \\
\hline $\mathrm{Pu}$ & - & $\begin{array}{l}4.115 \\
4.140\end{array}$ & MCDONALd et al. (1960) \\
\hline Am & - & 4.1154 & EICK and MULFORD (1969) \\
\hline
\end{tabular}


b) $\mathrm{ThB}_{4}$-Type Tetraborides

Elements likely to form tetraborides of $\mathrm{a} \mathrm{ThB}_{4}$ type are yttrium, lanthanides except europium, as well as some actinides: thorium, uranium, neptunium, plutonium and americium (BERTAUT and BLUM, 1949; ZALKIN and TEMPLETON, 1953).

The crystal structure of the phases with tetragonal symmetry ( $\mathrm{P} 4 / \mathrm{mbm}$, $D_{4 h}$ ) can be described as follows: the boron covalent sublattice is formed by chains of $\mathrm{B}_{6}$ octahedra, developing along the c-axis, and by pairs of $\mathrm{B}_{2}$ atoms, bonding the octahedra in the xOy plane (Fig. 2). The resulting three-dimensional skeleton contains tunnels parallel to the c-axis that are filled by metal atoms (ZALKIN and TEMPLETON, 1953).

Because of the many common features of $\mathrm{CaB}_{6}$ and $\mathrm{ThB}_{4}$-type structures (covalent skeleton, $B_{6}$ octahedra, existence of boron "cages" ...), deviations from stoichiometry can be expected for tetraborides. The few studies made in this field concern only parameter values (EICK and MULFORD, 1969; JOHNSON and DAANE, 1961). Their results are too contradictory to allow a precise evaluation of the limits of possible homogeneity ranges. However it can reasonably be assumed that deviations from stoichiometry must take place on the deficit side of the metal.

\section{Preparation}

Since boron readily combines with most metals and reduces refractory oxides at high temperatures, different methods can be utilized to prepare borides. Since fused salt electrolysis is only of historical interest for hexaboride and tetraboride synthesis, we shall describe only general methods such as direct synthesis from elements and reduction of oxides by boron at high temperatures. Special attention will be given to methods of crystal growth.

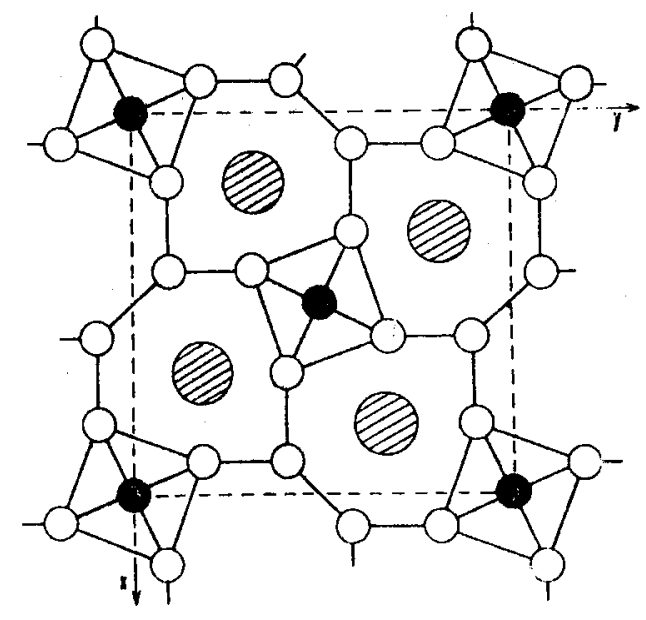

CO B 11 


\section{a) Direct Synthesis from Elements}

$$
M+Y B+M B_{Y} \quad(y=4 \text { or } 6) \text {. }
$$

The choice of the specific experimental technique is determined by the degree of volatility of the metal to be used.

\section{a) Direct Synthesis in the Presence of a Vapor Phase}

This technique is utilized when the metals involved have high vapor pressures at the temperatures required for synthesis. This is the case for potassium, alkaline earths, samarium, europium, thulium and ytterbium. The utilization of these relatively volatile metals requires sealed containers, that resist the corrosive action of boron and of metal gases under pressure (ETOURNEAU, 1970b).

\section{B) Direct Synthesis Involving Metals with Low Volatility}

The reactions are generally carried out in vacuum or an argon atmosphere. To facilitate solid-state diffusion, the boron and the metal (often as a finely divided hydride) are shaped into tablets under high pressure (about $15 \mathrm{~kb}$ ).

\section{b) Indirect synthesis}

The principle of this method is the reduction, at high temperatures, of metal oxides by boron. As a general rule, the reduction reaction can be described as follows:

$$
\text { metal oxide + boron } \stackrel{t>1500^{\circ} \mathrm{C}}{\longrightarrow} \text { boride }+\mathrm{B}_{2} \mathrm{O}_{2}{ }^{\star} \text {, }
$$

where the nature of the volatile boron oxide is not well defined.

Oxide-boron mixtures pressed into cylindrical tablets under high pressure, are treated either by arc-melting, or by high-frequency induction heating in tantalum, molybdenum or tungsten crucibles (ETOURNEAU, $1970 b)$. The elimination of oxygen in boron oxide generally requires that the reactions be carried out in vacuum.

Boron-carbon mixtures or $\mathrm{B}_{4} \mathrm{C}$ boron carbide make it possible to reduce metal oxides at lower temperatures. However their utilization presents one drawback, that of a risk of contamination by carbon. Consequently the preferred method of synthesis involves only boron itself as the reducing agent, since it is the only element that can provide materials that are well characterized and of high purity.

\section{c) Single Crystal Growth}

Several crystal growing methods have been utilized in the preparation of tetraboride and hexaboride single crystals.

\section{a) Chemical Transport}

RABENAU, KAUER and KLOTZ obtalned lanthanum hexaboride crystals $(0.15 \times$ $0.15 \times 2 \mathrm{~mm}^{3}$ ) by chemical transport in the presence of bromine. The reaction was carried out in a sealed ceramic $\left(\mathrm{SiO}_{2}\right.$ and $\left.\mathrm{Al}_{2} \mathrm{O}_{3}\right)$ flask with a thermal gradient between 1105 and $1095^{\circ} \mathrm{C}$ (KLOTZ, 1965). NIEMYSKI and KIERZEK-PECOLD used a $\mathrm{BCl}_{3}+\mathrm{H}_{2}$ mixture as a transport. agent that reacted with lanthanum oxide. Here the temperatures of both the cold and the hot sources were much higher $\left(1000\right.$ and $\left.1450^{\circ} \mathrm{C}\right)$. The edges of the crystals obtained were about one millime oer in length (NIEMYSKI and KIERZEK-PECOLD, 1968). 


\section{B) lezting with a Metal Excess}

These reactions are carried out in open or sealed containers, according to the volatility of the metals involved. JOHNSON and DAANE, and later DEACON and HISCOCKS obtained prismatic $L_{a B_{4}}$ needles 5 to $8 \mathrm{~mm}$ long as well as small $\mathrm{SrB}_{6}$ single crystals $(0.2 \mathrm{~mm}$ approximately) by slow cooling $\left(16^{\circ} \mathrm{C} / \mathrm{h}\right.$ ) from $1700^{\circ} \mathrm{C}$ (JOHNSON and DAANE, 1961; DEACON and HISCOCKS, 1971).

FISK et al. (1972) prepared single crystals of tetraborides of the first members of the rare earths (La to Nd) by this method.

\section{r) Zone-Melting}

zone-melting is an appropriate method for crystallization of congruentmelting compounds.

JOHNSON and DAANE (1963) obtained large yttrium tetraboride crystals (6 $\mathrm{mm}$ diameter and $10 \mathrm{~cm}$ long, approximately).

CURTIS and GRAFFENBERGER (1966), followed by NIEMYSKI and KIERZEKPECOLD (1968) prepared, with a floating zone technique, lanthanum hexaboride single crystals from 4 to $10 \mathrm{~mm}$ long and with $3 \mathrm{~mm}^{2}$ in cross section, approximately.

\section{d) Utilization of a Metal Flux}

Aluminum is generally used as the metal flux. The method consists in heating up to $1550^{\circ} \mathrm{C}$ in an argon atmosphere a boron + metal mixture (in stoichiometric proportions) in the presence of a large excess of aluminum, then to let the molten mass cool down to $1000^{\circ} \mathrm{C}$ within $10 \mathrm{~min}$, and finally to stop abruptly the heating.

FISK et al. (1972) thus obtained single crystals of tetraborides of the heavy rare-earths (from Sm to $L u$, except Eu). With the same technique, STURGEON et al. (1974) prepared samarium hexaboride single crystals as well as (Eu, Sm) $B_{6}$-crystals a few millimeters in length.

d) Conclusion

A review of the methods of hexaboride and tetraborlde preparation shows that indirect synthesis by borothermal reduction of oxides appears to be the most satisfactory and easiest method to apply when large quantities of borides are needed. It also makes it possible to obtain $M_{x} M^{\prime} 1-x_{6} B_{6}$ (or $M_{x} M_{1}^{1}-x_{4}$ ) solid solutions with perfectly defined compositions.

However a detailed study of the physical properties of these materials - already quite developed concerning polycrystalline samples - more and more often requires single crystals. Consequently the previously described crystal growth techniques will have to be refined in order to fulfill the more and more demanding requirements of single crystal studies.

\section{Therma? Stability}

A study of the thermal stability of materials over a large temperature range provides a most helpful guide in the determination of ideal preparation conditions, for polycristalline samples as well as for single crystals. 
a) Experimental Results

The thermal behavior of hexaborides and tetraborides can be described with the help of reaction mechanisms involving either congruent melting or dissociation through preferential evaporation of metal or boron (ETOURNEAU, et al., 1972a, b).

a) Hexaborides

There are four classes of compounds from the point of view of stability:

a) $\mathrm{M}=\mathrm{La}, \mathrm{Ce}, \mathrm{Pr}, \mathrm{Nd}, \mathrm{Sm}$ or $\mathrm{Am}$ :

$\mathrm{MB}_{6} \rightarrow$ congruent melting.

b) $\mathrm{M}=\mathrm{K}, \mathrm{Ca}, \mathrm{Sr}, \mathrm{Ba}$ or Eu:

$\mathrm{MB}_{6} \rightarrow \mathrm{M}^{*}+6 \mathrm{~B}$ (boron residue)

c) $M=Y, G d, T b, D Y$ or $T h$ :

$\mathrm{MB}_{6}+\mathrm{MB}_{4}+2 \mathrm{~B}^{x}$

d) $\mathrm{M}=\mathrm{Yb}$ :

$2 \mathrm{MB}_{6} \rightarrow \mathrm{MB}_{12}+\mathrm{M}^{\pi}$

B) Tetraborides

There are two classes of compounds:

a) $M=Y, G d, T b, D y, H o, E r, T m, L u, U$ or $P u$ :

$\mathrm{MB}_{4} \rightarrow$ congruent melting

b) $\mathrm{M}=\mathrm{La}, \mathrm{Ce}, \mathrm{Pr}, \mathrm{Nd}, \mathrm{Sm}$ or $\mathrm{Yb}$ :

$\mathrm{MB}_{4} \rightarrow \mathrm{MB}_{6}+\mathrm{M}$

b) Discussion

a) Relative Stability of Hexaborides

The interpretation of thermal behavior of hexaborides is based on two factors: the saturation vapor pressure of the metal, an increase of which increases the dissociation, and the stability of the B-B bonds within the boron sublattice, the strength of the $B-B$ bonds decreasing as the size of the cubic lattice parameter increases.

The great stability of hexaborides from lanthanum to neodymium can be explained by the progressive contraction of the lattice, which compensates for the increasing volatility of the metal. Samarium hexaboride, thermally very stable, is the limiting case with regard to volatility of metal which is high, but the lattice parameter is still relatively small, since it is intermediate between those of $\mathrm{CeB}_{6}$ and $\mathrm{PrB}_{6}$ (Figs. 3 and 4 ).

The thermal behavior of $\mathrm{EuB}_{6}$ and $\mathrm{YbB}_{6}$ is a result of the high volatility of the metals, and also of the great dilatation of the unit cell and consequently of the fragility of the $B-B$ bonds. The exceptional volatility of ytterbium explains the fact that $\mathrm{YbB}_{6}$ is less stable than $\mathrm{LaB}_{6}$, although their unit cells have very nearly the same size.

The dissociation of $\mathrm{YB}_{6}, \mathrm{GdB}_{6}, \mathrm{TbB}_{6}$ and $\mathrm{DyB}_{6}$ hexaborides into tetraborides with loss of boron at $1550^{\circ} \mathrm{C}$, is a consequence of the volatility of boron at this temperature, and also of the very high stability of the corrosponding tetraborides. 


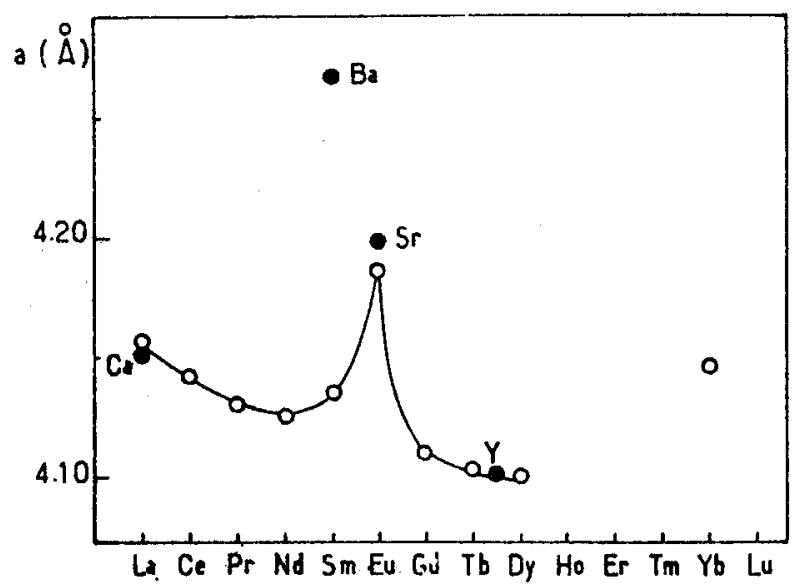

Fig. 3. Lattice parameters of rare-earth hexaborides

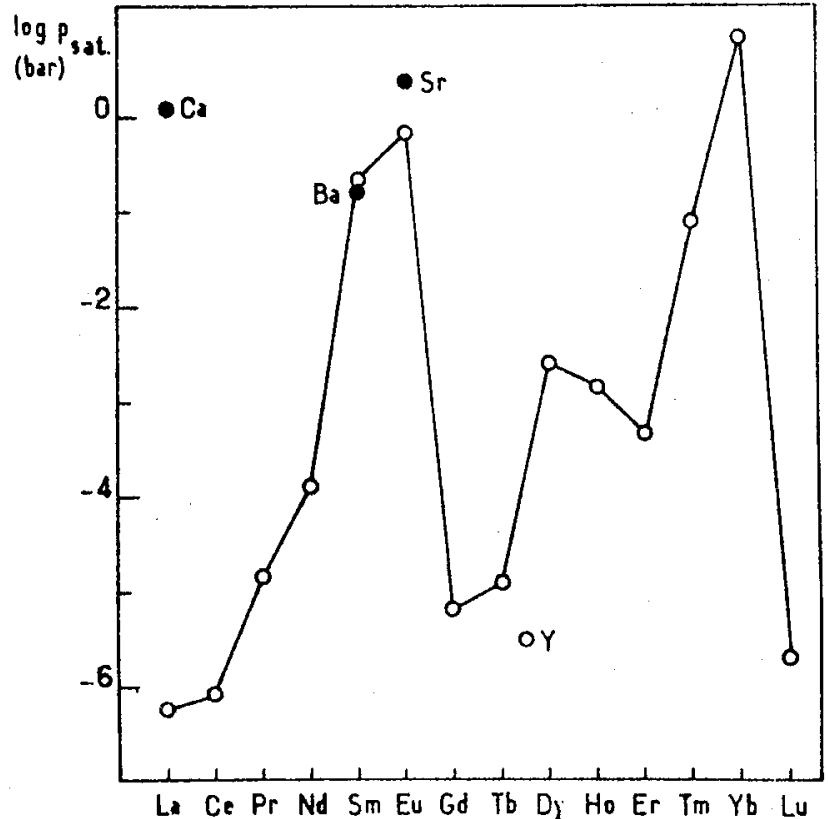

Fig. 4. Saturation vapor pressures of rare-earths at $1800 \mathrm{~K}$

The interpretation proposed for the $\mathrm{LnB}_{6}$ phases can be extended to alkaline-earth and potassium hexaborides. These dissociate through metal evaporation, yielding a $\beta$-rhomboedral boron residue, at the melting-point in the case of $\mathrm{CaB}_{6}, \mathrm{SrB}_{6}$ and $\mathrm{BaB}_{6}$, and at $750^{\circ} \mathrm{C}$ in the case of $\mathrm{KB}_{6}$ (ETOURNEAU, 1970b; NASLAIN and ETOURNEAU, 1966).

For a given volume of the unit cell, the most stable hexaborides will be that which corresponds to the least volatile metal: LaB 6 is then more stable than $\mathrm{CaB}_{6}$, in spite of their identical parameters.

on the other hand, for comparable metal vapor pressure, the most stable hexaboride will be that which has the smallest unit cell: $\mathrm{SmB}_{6}$ is indeed moore stable than Ball, which has a lager unit cell. 
The fact that europium and strontium have comparable volatilities and also B-B bonds of identical strength accounts for the similar thermal behavior of $\mathrm{EuB}_{6}$ and $\mathrm{SrB}_{6}$.

In the same way one can explain the easy dissociation of $\mathrm{KB}_{6}\left(\mathrm{a}_{\mathrm{KB} G}=\right.$
$\left.4.232 \AA, \mathrm{p}_{\mathrm{K}}^{1700} \mathrm{~K}=27 \mathrm{bar}\right)$.

B) Relative Stability of Tetraborides

The temperatures at which dissociation of tetraborides (under $10^{-6}$ torr) begins are the following:

$\mathrm{LaB}_{4}: 1850^{\circ} \mathrm{C} ; \mathrm{CeB}_{4}: 2200^{\circ} \mathrm{C} ; \mathrm{PrB}_{4}: 1950^{\circ} \mathrm{C} ; \mathrm{NaB}_{4}: 1850^{\circ} \mathrm{C}$;

$\mathrm{SmB}_{4}: 1650^{\circ} \mathrm{C}$.

Thus, while the thermal stability increases from $\mathrm{LaB}_{4}$ to $\mathrm{CeB}_{4}$, there is a monotonic decrease with increasing atomic number from $\mathrm{CeB}_{4}$ to $\mathrm{SmB}_{4}$.

PADERNO and POKRZYWNICKI (1967a) showed, by studies of magnetic properties, that the inserted rare earth ion for $\mathrm{GdB}_{4}$, DyB 4 . $\mathrm{HOB}_{4}, \mathrm{ErB}_{4}$ and $\mathrm{TmB}_{4}$ was in +III oxidation state. Figure 5 shows that this is also the case for the other tetraborides except of $\mathrm{CeB}_{4}$ and $\mathrm{YbB}_{4}$. The $\mathrm{ab}-$ normal volume contraction for $\mathrm{CeB}_{4}$ unit cell observed by many authors, can certainly be explained by the presence (at least partially) of Ce ions (GSCHNEIDNER, 1961). On the other hand, the dilatation of $\mathrm{YbB}_{4}$ could be the result of the presence of $\mathrm{Yb}^{2+}$ ions (FISK et al., 1972 ).

The trend in thermal stability observed for $\mathrm{LaB}_{4}, \mathrm{CeB}_{4}, \operatorname{PrB}_{4}, \mathrm{NdB}_{4}$ and $\mathrm{SmB}_{4}$ is explainable by the counteracting effects of increasing metal volatility and decreasing unit cell volume. The first effect accounts for the lesser stability of $\mathrm{LaB}_{4}$ relative to $\mathrm{SmB}_{4}$ and the second for the maximum at $\mathrm{CeB}_{4}$.

For comparable metal volatilities, the tendency to dissociate decreases with shortening of $\mathrm{B}-\mathrm{B}$ distances. The high thermal stability of $\mathrm{YB}_{4}$, $\mathrm{GdB}_{4}, \mathrm{TbB}_{4}, \mathrm{DYB}_{4}, \mathrm{HOB}_{4}$ and $\mathrm{ErB}_{4}$ is the result of the combination of both a relatively low metal volatility and a small unit cell volume.

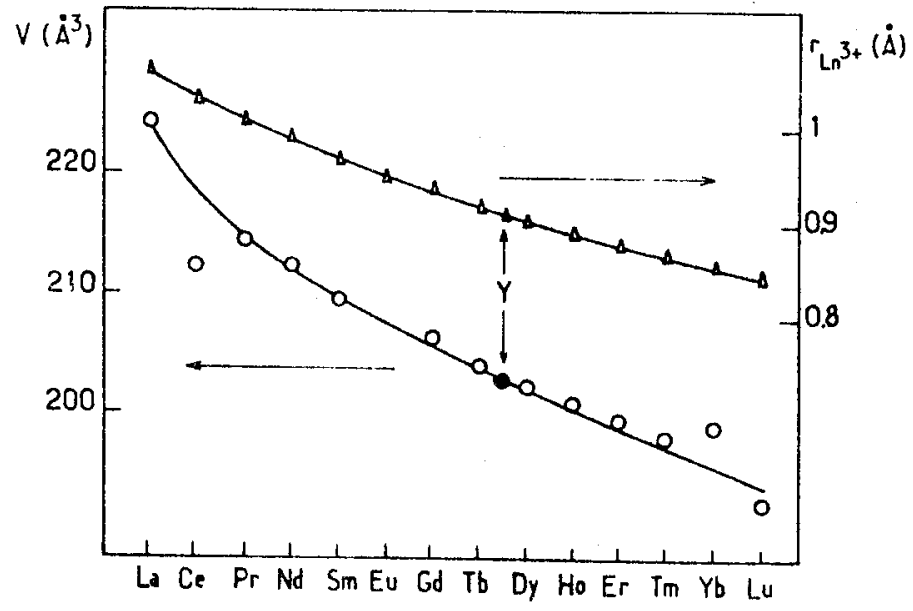

Fig. 5. Elementary volume of rare-earth tetraborides and ionic radii of rareearth tetraborides in the +II oxidation state 
$\mathrm{EuB}_{4}$ and $\mathrm{YbB}_{4}$ are difficult to obtain because of the high vapor pressure of europium and ytterbium. However this factor is not sufficient to explain why $\mathrm{EuB}_{4}$ has never been prepared to date: an equally important factor could be the large unit cell that would result for a II oxidation state, by analogy with $\mathrm{YbB}_{4}$.

\section{c) Structural Observations}

A basis for comparison of the $\mathrm{CaB}_{6}$ and $\mathrm{ThB}_{4}$ structure types is the dimension of the site available for the metal atoms within the boron sublattice. Table 2 gives the extrema of the radil of these sites, calculated from average B-M distances, assuming the atomic radius of boron $\left(x_{B}=0.88 \AA\right.$ ) does not significantly vary from one structure to another (NASIAIN, et al., 1973). It also shows the extrema for metal and ion radii of the elements that might form hexaborides and tetraborides (SHANNON and PREWITT, 1969). The site for metal occupancy for the hexaborides is noticeably larger than for tetraborides, as can be predicted from their respective coordinations ( 24 in $\mathrm{MB}_{6}$ phases, $16+2$ in $\mathrm{MB}_{4}$ phases).

Table 2.

\begin{tabular}{llll}
\hline Structure type & Radii of metal sites $(\AA)$ & $r_{M}(\AA)$ & $r_{M^{3}}+(\AA)$ \\
\hline$M_{6}$ & $2.26-2.14$ & $2.23-1.75$ & $1.28-0.92$ \\
$M_{4}$ & $1.99-1.87$ & $1.95-1.68$ & $1.14-0.85$ \\
\hline
\end{tabular}

The available sites in hexaborides will then accommodate atoms larger than those in tetraborides. This is one of the reasons why large atoms such as $\mathrm{Ca}, \mathrm{Sr}, \mathrm{Ba}, \mathrm{Eu}$, and $\mathrm{Yb}$ can form hexaborides, whereas the small rare earths (Ho, Er, Tm, Lu) cannot.

The metal sites in tetraborides by contrast accomodate smaller atoms: this explains the great thermal stability of tetraborides of the heaviest trivalent rare earths (Gd to Lu). As in the rare earth series only europium - whose radius is large for the divalent state $\left(r_{E u} 2+=\right.$ $1.12 \mathrm{~A}$ ) - does not form any tetraborides, and because of the questionable existence of $\mathrm{CaB}_{4}$, we consider the size of the calcium ton $\left(x_{\mathrm{Ca}^{2}+}=0.99 \AA\right)$ as the upper limit for insertion of a metal ion into the boron sublattice. The fact that cerium is, at least partially, in $a+I V$ oxidation state in $\mathrm{CeB}_{4}$ and in a +III oxidation state in CeB, is in agreement with this conclusion.

\section{Physical Properties}

This section is concerned mainly with the study of electrical and magnetic properties of the $\mathrm{ThB}_{4}$-type tetraborides and of the hexaborides.

\section{a) Hexaborides}

Since the publication in 1950 of the first physical data concerning $\mathrm{CaB}_{6}$-type hexaborides, many band structure models have been proposed based on theoretical considerations, generally involving a LCAO-type approximation for atomic orbitals of boron (LONGUET-HIGGINS and ROBERTS, 1954; YAMAZAKI, 1957; FLODMARK, 1960; PADERNO et al., 1970). 
The calculations made by LONGUET-HIGGINS and ROBERTS (1954) led to a model consisting of four bonding orbitals, which could contain 20 electrons per $\mathrm{MB}_{6}$ group, separated from four anti-bonding orbitals by a forbidden band. For a $\mathrm{MII}_{\mathrm{B}_{6}}$ divalent element hexaboride, the 18 electrons donated by 6 boron atoms and the two valence electrons of the metal atom completely fill the bonding orbitals: thus MII $_{B_{6}}$ is an insulator or a semiconductor. For $\mathrm{CaB}_{6}$ the calculated width of the forbidden band was $4.4 \mathrm{eV}$, but YAMAZAKI (1957) obtained a value of $1.5 \mathrm{eV}$. If the metal atom yields more than two electrons, the extra electrons partially fill an anti-bonding band and the hexaboride becomes metallic.

In FLODMARK's Calculations the wave functions relative to the $3 \mathrm{~s}, 3 \mathrm{p}$ and even $3 \mathrm{~d}$ boron orbitals were included (FLODMARK, 1960). The band occurring from the new orbital combinations and those obtained from solely $2 s$ and $2 p$ orbitals are different: in the new energy diagram, totaly occupied bonding bands can accommodate 12 electrons and partially occupied conduction bands the remaining electrons. $\mathrm{CaB}_{6}-t y p e$ hexaborides would then be, according to this model, compounds of a metallic character, whatever the number of electrons provided by the metal.

Both methods of calculation lead to the same conclusion that for a metal in a III or +IV oxidation state, the corresponding boride is metallic. They differ markedly, however, in their predictions for hexaborides containing divalent elements.

It is in order, however, to question the significance of either model, since they both lead to contradictions with certain experimental facts, for example $\mathrm{CaB}_{6}$ and $\mathrm{SxB}_{6}$ are all semiconductors contrary to the predictions of FLODMARK's model.

The LONGUET-HIGGINS and ROBERTS model has shortcomings regarding its predictions for hexaborides containing less than two electrons per metal site. The model requires that the metal donates at least two electrons and that the number of electrons per $\mathrm{MB}_{6}$ group be 20 . But BERTAUT and BLUM have shown the existence of sodium substitutions in $\mathrm{BaB}_{6}$ and $\mathrm{ThB}_{6}$ corresponding to the formulas $\mathrm{N}_{0}{ }_{4}{ }_{3} \mathrm{~B}_{0} ._{7} \mathrm{~B}_{6}$ and $\mathrm{Na}_{0}{ }_{77}$ $T_{h}{ }_{2}{ }_{3} B_{6}$, where the number of electrons per group was respectiveiy 19.57 and 19.69 (BLUM and BERTAUT, 1954). This difference is still greater in $\mathrm{KB}_{6}$ prepared by NASLAIN and ETOURNEAU (1966), where only 19 electrons are available. The existence and the stability of $\mathrm{KB}_{6}$ of the former ternary hexaborides show that their lattices are stable in the case of an electron concentration below two per inserted atom.

It was not possible to test the validity of the proposed models and possibly to make necessary modifications until significant progress had been made in the preparation of high purity poly- or single crystalline materials that were thoroughly characterized.

a) Transport Properties

$\mathrm{M}^{I I \mathrm{I}_{6}}$ and $\mathrm{M}^{\mathrm{IV} \mathrm{B}_{6}}$ hexaborides ( $\mathrm{M}=\mathrm{Y}, \mathrm{La}, \mathrm{Ce}, \mathrm{Pr}, \mathrm{Nd}, \mathrm{Gd}, \mathrm{Tb}, \mathrm{Dy}$ and $\mathrm{Th}$ )

These hexaborides have a metal-type conductivity, the value of which, at room temperature, is in the range of $10^{4}$ to $10^{5} \Omega^{-1} \mathrm{~cm}^{-1}$ (ETOURNEAU et al., 1970a; LAF'FERTY, 1951; SAMSONOV et al., 1963; AUSKERN and ARONSON, 1968). The Hall effect measurements show that the number of conduction electrons is close to one per metal atom for trivalent hexaborides and to two per thortum atom for ThB 6 (JOHNSON and DAANE, 1963; SAMSONOV ot al., 1963; AUSKERN and ARONSON, 1968). The thermoelectric power has a value of a fow $\mu \mathrm{VK}^{-1}$ at room temperature, con- 
firming the metaliic character of these compounds (SAMSONOV et al., 1963; ETOURNEAU et al., 1970).

We must also note that studies on electronic specific heat at low temperatures have led ETOURNEAU et al. (1970) to find that the density of states at the Fermi level is not zero, but of the same order of magnitude as for the metallic rare earths.

$\mathrm{M}^{\mathrm{I} \mathrm{I}_{6}}$ Hexaborides $(\mathrm{M}=\mathrm{Ca}, \mathrm{Sr}, \mathrm{Ba}, \mathrm{Eu}$ and $\mathrm{Yb})$

The high value of the lattice parameter of $\mathrm{EuB}_{6}$ and $\mathrm{YbB}_{6}$ compared to those of hexaborides of the other rare earths, as well as magnetic studies and Mössbauer resonance studies have shown that, among these compounds, europium and ytterbium were in a +II oxidation state (POST et al., 1956; PADERNo et al., 1967; COHEN, 1968).

By measuring electrical conductivity on single crystals, JoHNSON and DAANE (1963) established that $\mathrm{CaB}_{6}, \mathrm{SrB}_{6}$ and $\mathrm{BaB}_{6}$. were sericonductors with activation energies of $0.40,0.38$ and $0.12 \mathrm{eV}$ respectively. SAMSONOV et al. (1963) reported, from Hall effects measurements, conduction electron concentrations below 0.1 per metal atom for CaB $\mathrm{B}_{6}$, $\mathrm{SrB}_{6}$, $\mathrm{BaB}_{6}$, EuB 6 and $\mathrm{YbB}_{6}$. Recently FISK (1969) confirmed the semiconductor behavior of $\mathrm{EuB}_{6}$ and $\mathrm{YbB}_{6}(\Delta \mathrm{E}=0.38 \mathrm{eV}$ for EuB 6$)$, as well as MERCURIO et al. (1973) ( $\Delta \mathrm{E}=0.30$ for $E^{2 u B_{6}}$ and $0.14 \mathrm{eV}$ for $\left.\mathrm{YbB}_{6}\right)$, by measurements on sintered bars (Fig. 6) (GOODENOUGH et al., 1973).

For all hexaborides containing a metal in the +II oxidation state, the thermoelectric power is high in absolute value (MERCURIO et al., 1973; GOODENOUGH et al., 1973). Measurements of specific heat with electron state densities at the Fermi level close to zero for $\mathrm{YbB}_{6}$, $\mathrm{CaB}_{6}$ and $\mathrm{SrB}_{6}$ have confirmed the semiconductor nature of the $\mathrm{MII}^{\mathrm{I}_{6}} \mathrm{~B}_{6}$ hexaborides (ETOURNEAU et al., 1970a)

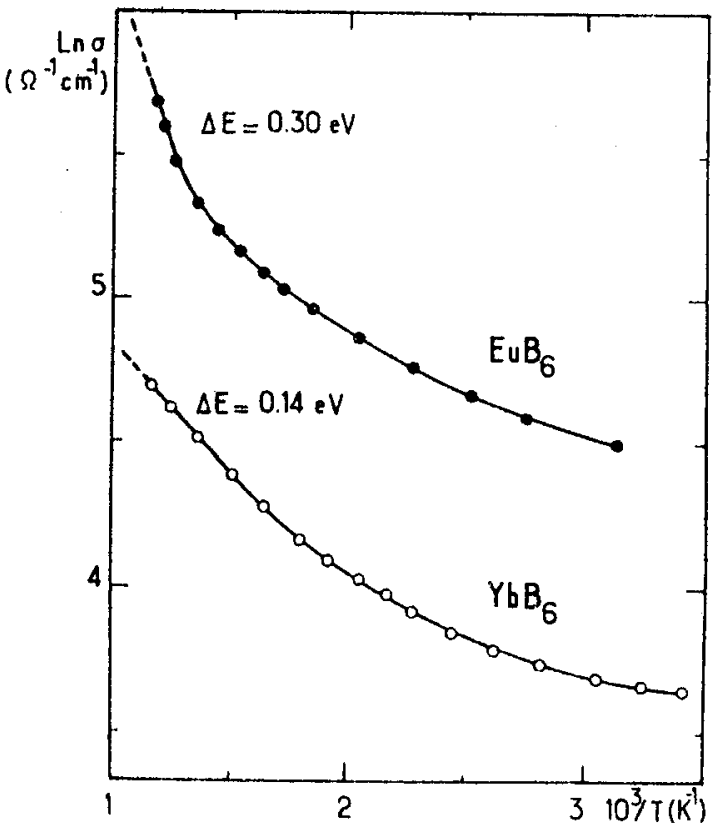

Fig. 6. Electrical conductivity of $\mathrm{EuB}_{6}$ and $\mathrm{YbB}_{6}$, plotted vs reciprocal temperature 


\section{$M_{1-x}^{I I} M_{x}^{I I I} B_{6}$ Ternary Hexaborides}

These compounds are interesting because of the simultaneous presence of elements in +II and +III oxidation states. By measuring electrical conductivity and thermoelectric power as a funtion of $x$, one can follow the development of their proerties fxom semiconductor $\left(\mathrm{M}^{\mathrm{I}} \mathrm{I}_{\mathrm{B}_{6}}\right)$ to metallic (MIII $\mathrm{B}_{6}$ ) behavior. In the case of $\mathrm{La}_{\mathrm{A}} \mathrm{Eu}_{1-\mathrm{x}_{6}} \mathrm{~B}_{6}$ solid solutions, a sudden transition from a semiconductor to a metal has been observed (MERCURIo et al., 1974). The semiconductor character of $E_{1} \mathrm{~B}_{6}$ disappears as soon as $x=0.01$, while the metallic characte:- grows as $x \rightarrow 1$ (Fig. 7). The Seebeck coefficient variation is high for small values of $x$, but quickly reaches a value near to that obtained for $\mathrm{LaB}_{6}$ when $x$ increases (Fig. 8).

Thus, the substitution of europium by $\mathrm{La}^{3+}$ ions - in small quantities annihilates the semiconductor character of $\mathrm{EuB}_{6}$, since the occurrence of electrons donated by lanthanum to the conduction band creates a metallic-type conductivity.

\section{Samarium Hexaboride}

For $\mathrm{SmB}_{6}$ although the unit cell dilation is much less than for $\mathrm{EuB}_{6}$ and $\mathrm{YbB}_{6}$, it is still sufficient for samarium hexaboride to be considered as an intermediate compound between the $M^{I^{I} I_{B_{6}}}$ and $M^{I I I_{B_{6}}}$ types (Fig. 3).

Electrical conductivity measurements carried out on polycrystalline samples as well as on single crystals, show that $\mathrm{SmB}_{6}$ behaves as a semiconductor with a very low activation energy at low temperatures: $\triangle E \approx 5.10^{-3} \mathrm{eV}$ (Fig. 11) (STURGEON et al., 1974; MENTH et al., 1969; FALICOV and KIMBALL, 1969; COHEN et a1., 1970; GEBALLE et al., 1970; NICKERSON et al., 1971). The thermal variations of the Hall coefficient

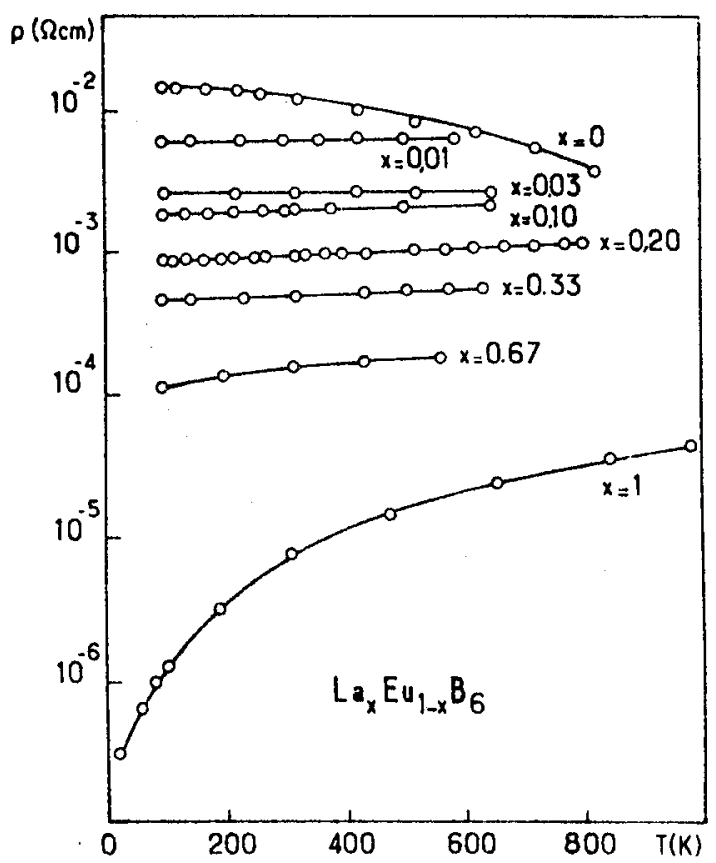

Fig. 7. Resistivity of $\mathrm{La}_{x} \mathrm{Eu}_{1-\mathrm{x}^{\mathrm{B}}}$ solid solutions as a function of temperature 


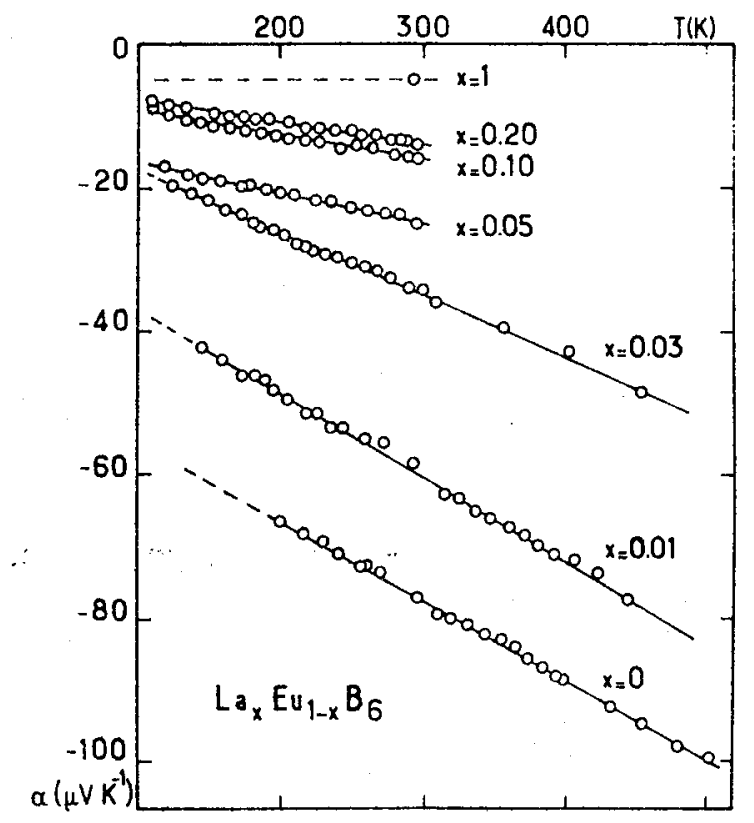

Fig. 8. Thermoelectric power of $\mathrm{La}_{x^{\mathrm{Eu}}}-x^{B_{6}}$ solid solutions as a function of temperature

and of the thermoelectric power seem to correspond first to localized electron conduction and then to highly mobile carriers with rising temperature. It appears that $4 \mathrm{f}^{6}+4 \mathrm{f}^{5} 5 \mathrm{~d}^{1}$ transition takes place. The d-electrons are initially localized by disordered potentials (Anderson localization) at the bottom of the conduction band, they become progressively delocalized as higher energy levels are occupied.

\section{Energy Diagrams}

The models described above are appropriate only to $\mathrm{CaB}_{6}$, taking simply into account the atomic orbitals of boron. To extend these models to the whole family of $\mathrm{CaB}_{6}$-type hexaborides and particularly to rareearth hexaborides, one must consider not only the $B_{6} \sigma$ bonding band and $\mathrm{B}_{6} \sigma^{*}$ anti-bonding bands, but also the participation of the rareearth $5 d$ and $6 \mathrm{~s}$ orbitals.

$M I I I_{B_{6}}$ Hexaborides. Two of the three valence electrons of the metal are donated to the boron skeleton and fill the $B_{6} \sigma$ bonding bands, the third one occupies a conduction band. It is reasonable to consider that the conduction electrons occupy a $5 d-6 s$ band originating from the rare-earths and not an anti-bonding $B_{6} \sigma^{*}$ band which would disturb the stability of the boron framework. This pattern can be extended to actinide hexaborides, involving $6 \mathrm{~d}$ and $7 \mathrm{~s}$ orbitals.

$M^{I I_{B_{6}}}$ Hexaborides. This concerns mostly europium and ytterbium hexaborides. For $\mathrm{EuB}_{6}$ it can be assumed that the Eu2+: $4 \mathrm{f}^{2}$ level is situated in the forbidden band (as for EuO). Europium vacancies would introduce holes in the $4 f^{7}$ configuration. These holes are small polarons, i.e. $\mathrm{Eu}^{3}+$ ions trapped by electrostatic forces on a site near-neighbor to the vacancy. The density of these acceptor sites is $\mathrm{N}_{A}$; the negative value of the Seebeck coefficient indicates that electron donor sites are also present actually with a $N_{D}>N_{A}$ density. These are rare earths in a state of substitutional impurity, represented in Figure 9 by the 


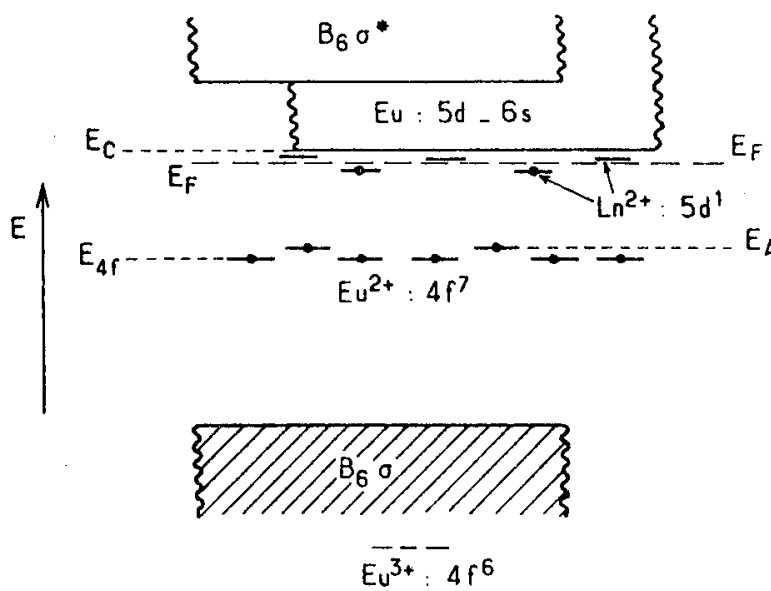

Fig. 9. Energy diagram for $\mathrm{EuB}_{\mathrm{B}}$

$5 \mathrm{~d}^{1}$ donor levels of $\mathrm{Ln}^{2+}: 4 \mathrm{fn}^{-1} 5 \mathrm{~d}^{\mathrm{l}}$ centers. When the density of impurity atoms is sufficient, a narrow $5 \mathrm{~d}^{1}$ impurity band is formed: since $N_{D}-N_{A}<N_{D}$, the Fermi level drops down to this narrow $5 d^{l}$ band.

Figure 6 shows that in the case of EuB $_{6}$ and $\mathrm{YbB}_{6}$, the electrical conductivity, in a temperature range of 77 to $300 \mathrm{~K}$ approximately, occurs only because of electrons moving within the impurity band excited in the conduction band. Only at very high temperatures the excitations of electrons situated in $4 \mathrm{f}^{7}\left(\mathrm{EuB}_{6}\right)$ or in $4 \mathrm{f}^{14}\left(\mathrm{YbB}_{6}\right)$ levels have to be taken into consideration. The Iinear variation with temperature of the seebeck coefficient shows, however, that the Fermi level remains located in the $5 \mathrm{~d}^{1}$ band, even at the highest temperatures. Accordingly, the 0.30 and $0.14 \mathrm{eV}$ values do not represent an intrinsic forbidden gap for $4 \mathrm{f}^{7}$ or $4 \mathrm{f}^{14}$ electrons.

In the case of $\mathrm{La}_{x} \mathrm{Eu}_{1-x^{\mathrm{B}}} \mathrm{B}_{6}$ solid solutions, the mobility - and consequently the conductivity - increases with $x$, because the Eu $2+$ ions, whose number is decreasing, behave as high electron-scattering centers. For low values of $x(x \leq 0.03)$ the electron mobility increases very quickly with $x$ : indeed, the conduction takes place inside a narrow lanthanum impurity band which widens with $x$ and progressively overlaps the bottom of the $5 d-6 s$ conduction band of europium as the number of lanthanum atoms increases.

A transition from semiconductor to metal appears between $x=0$ and $\mathbf{x}=0.01$. For higher values of $\mathbf{x}$, the Fermi level is higher than $\mathrm{E}_{C}$, the energy at which the electrons are no longer correlated. Tris transition has a less noticeable influence on the thermoelectric power. The curves of Figure 8 can be interpreted by the presence of chemical com. position inhomogeneities which would give rise to microphases, one corresponding to a polaron conduction, the other to an impurity band conduction. As long as the impurity band ranges are isolated, the material is a semiconductor, but when they become continuous, the conduction is metallic (MERCURIO et al., 1974).

Samarium Hexaboride. Since the rare-earth hexaborides in a +III oxidation state are metallic, the semiconductor character of $\mathrm{smB}_{6}$ seems to exclude the presence of $\mathrm{Sm}^{3+}: 4 \mathrm{f}^{5}$ ions. However, when samarium is in + II oxidation state, the $\mathrm{Sm}^{2+}$ ions can have both configurations $4 \mathrm{f}^{6} 5 \mathrm{~d}^{0}$ and $4 \mathrm{f}^{5} 5 \mathrm{~d}^{1}$, the former being obviously more stable than the latter 
because of the strong tendency of the rare earths to complete their 4 f subshell. COHEN et al. (1970) showed by Mössbauer absorption measurements that both configurations coexist in $\mathrm{SmB}_{6}$.

The very weak measured activation energy $\left(5.10^{-3}\right.$ eV) makes it plausible that the energy level diagram is similar to that of $\mathrm{EuB}_{6}$ and that localized $5 \mathrm{~d}^{\mathrm{l}}$ levels could be situated in the lower part of the $5 \mathrm{~d} 6 \mathrm{~s}$ conduction band (MERCURIO, 1974). The maximal energy $E_{C}$ of this zone would constitute a separation limit between localized and non-localized states, according to Anderson localization (Fig. 10).

At low temperatures $(<50 \mathrm{~K})$ strong electron-electron and electronlattice correlations take place within the $5 d^{1}$ localized levels. With rising temperature the thermal excitation allows electrons to pass progressively from these $5 \mathrm{~d}^{1}$ localized states to more and more delocalized states within a real conduction band $\mathrm{Sm}^{2+}: 5 \mathrm{~d} 6 \mathrm{~s}$ : the change in the slope of the $\operatorname{Ln} \sigma=f(1 / T)$ curve and the rapid decrease of $|a|$ between 100 and $200 \mathrm{~K}$ can be explained by a progressive increase in conduction by highly mobile carriers, i.e. by the transition to a metallic state (Figs. 11, 12).

The presence of electrons in the hybrid $5 \mathrm{~d} 6 \mathrm{~s}$ band reinforces their overlapping, which leads to a decrease in $\mathrm{Sm}-\mathrm{Sm}$ distances. The variation of the lattice parameter of $\mathrm{SmB}_{6}$ with temperature courld be the result of the competition between this overlapping phenomenon and the normal lattice dilatation with temperature, which becomes predominant above $70-80 \mathrm{k}$ (Fig. 13).

\section{B) Magnetic Properties}

Hexaborides of Non Magnetic Ions $\left(\mathrm{Ca}^{2+}, \mathrm{Sr}^{2+}, \mathrm{Ba}^{2+}, \mathrm{La}^{3+}, \mathrm{Th}^{4+}\right)$

These are diamagnetic, since their magnetic susceptibility is mostly caused by boron atoms. In the case of $\mathrm{YbB}_{6}:\left(\mathrm{Yb}^{2+}: 4 f^{14} 5 \mathrm{~d}^{0}\right)$ the observed weak paramagnetism may be due to presence of impurities in very low concentrations (ETOURNEAU et al., 1970; ETOURNEAU, 1970; RABENAU et al., 1967).

\section{Hexaborides of Magnetic Rare-Earths (MIII ${ }_{B_{6}}$ )}

These hexaborides become antiferromagnetic at low temperatures (MERCURIO, 1974; LEE and BELL, 1972; LEE et al., 1970; COLES and GRIFFITHS, 1961; BENOIT, 1955; PADERNO et al., 1969). While the effective moments calculated from experimental data in the paramagnetic range are close to the theoretical values obtained for free trivalent ions, there exists,

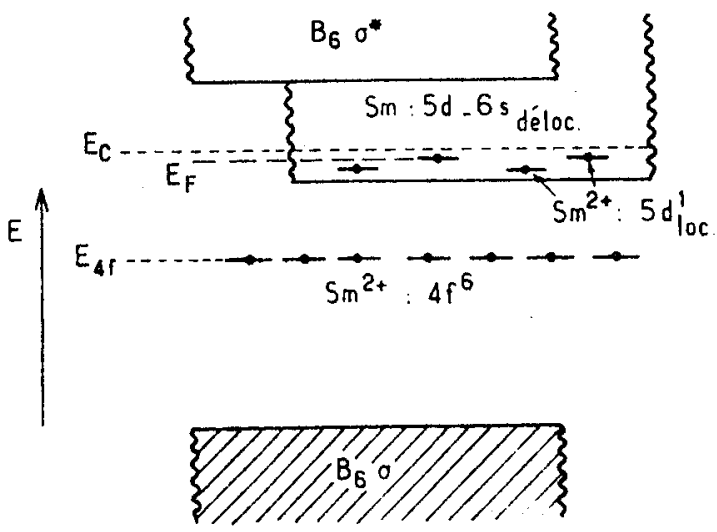




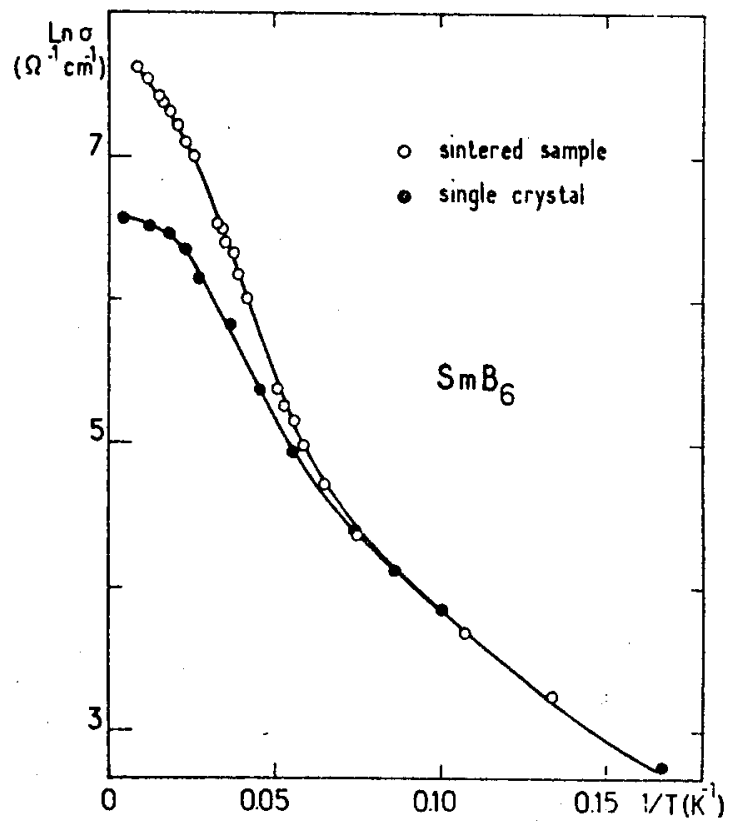

Fig. 11. Electrical conductivity of $\mathrm{SmB}_{6}$

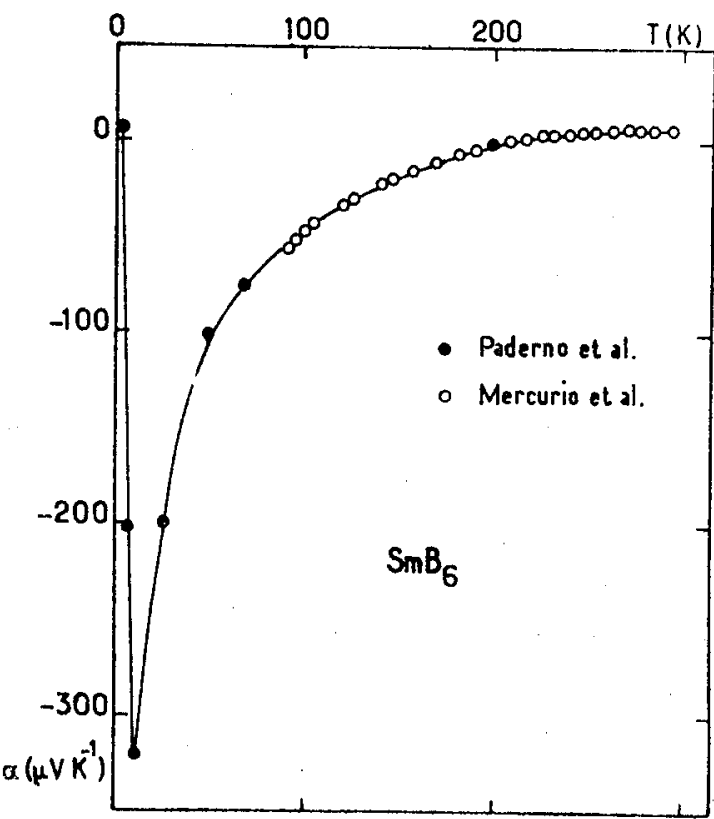

Fig. 12. Thermoelectric power of $\mathrm{SmB}_{6}$

however, a large difference between the values of $T_{N}$ and $\left|\theta_{0}\right|$, except for $\mathrm{DyB}_{6}$. It seems that this difference is caused by deviations with respect to the straight lines that represent the behavior of the free lons of the $x^{-1}=f(T)$ curves, when $T<100 \mathrm{~K}$ (Fig. 14). Since $M{ }^{2} I_{I_{B_{6}}}-$ type hexaborides are metals, it is reasonable to expect interaction of the local moments with the conduction electrons. This interaction 


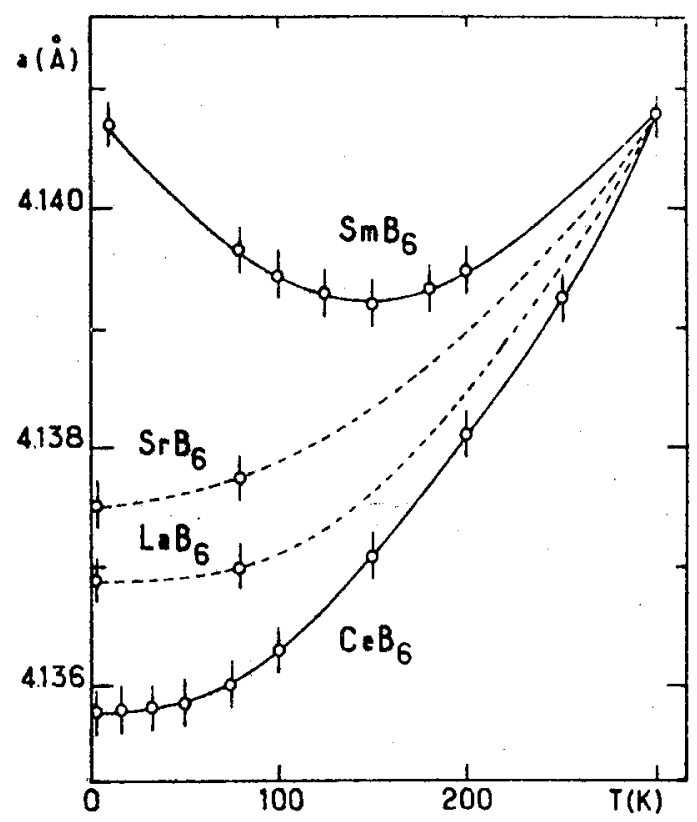

Fig. 13. Lattice parameters of some hexaborides as a function of temperature. The parameter values have been related to the $\mathrm{CeB}_{6}$ parameter at room temperature

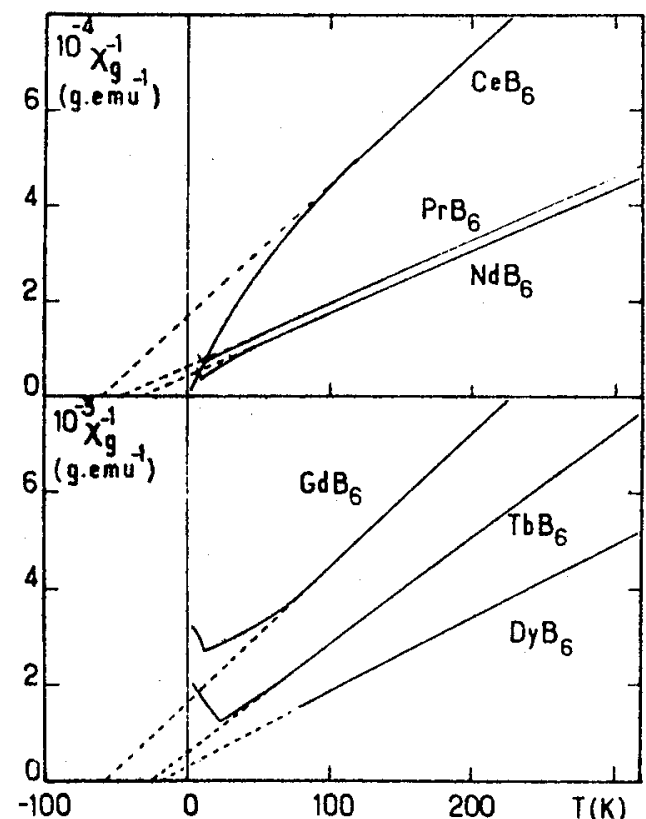

Fig. 14. Reciprocal magnetic susceptibility of rare-earth hexaborides

is of the form $H_{\text {int. }}=2 J_{s f} \vec{S} \vec{s}$, where $J_{s f}$ is the exchange integral between a magnetic ion characterized by a $\dot{S}$ spin caused by $4 \mathrm{f}$ electrons and the conduction electrons carrying the $\vec{s}$ spin. J sf polarizes the s electrons locally around the paramagnetic ion. Through the conduction electrons this local polarization gives rise to a large-distance interaction between localized moments. This phenomenon called Ruderman- 
Kittel-Kasuya-Yosida interaction provides at least a qualitative understanding of the antiferromagnetism of the rare-earth hexaborides in the +III oxidation state (RUDERMAN and KITTEL, 1954; KASUYA, 1956; YOSIDA, 1957).

Europium Hexaboride and $\mathrm{La}_{x} \mathrm{Eu}_{1-x \mathrm{~B}_{6}}$ Solid Solutions

EuB $_{6}$ orders ferromagnetically for $T<13 \mathrm{~K}$, the Curie temperature varying from 8 . to $13 \mathrm{~K}$ according to different investigators. The Curie constant determined in the paramagnetic range corresponds to the $4 \mathrm{f}^{7}$ $\left({ }^{8} \mathrm{~S}_{7 / 2}\right)$ configuration of the Eu ${ }^{2+}$ free ion in its ground state (MERCURIO et al., 1974; GEBALIE et al., 1968; BACHMANN et al., 1970; HACKER et al., 1971).

FISK (1969) explained the ferromagnetism of $\mathrm{EuB}_{6}$ by a modification of the RKKY interaction studied by BLOEMBERGEN and ROWLAND (1955) for semiconductors. According to these authors, the moments could be coupled through the valence band electrons. Their calculations, established with the aid of some simplifying assumptions lead to an exchange function that varies with the distance between inserted atoms; in the case of $\mathrm{EuB}_{6}$ the interaction would be ferromagnetic.

In the case of $\mathrm{La}_{\mathbf{x}} \mathrm{Eu}_{1-\mathrm{x} \mathrm{B}_{6}}$ solid solutions, the paramagnetic Curie temperature increases at the beginning, up to $20 \mathrm{~K}$ for $\mathrm{x}=0.03$, and then decreases to $-10 \mathrm{~K}$ for $\mathrm{x}=0.50$, after having passed through a zero value for $x \approx 0.33$. It starts increasing again for $0.50<x<0.75$ and vanishes for $\mathrm{x} \geq 0.75$ (Fig.15).

For small values of $x(x \leq 0.05)$ we saw that supplementary electrons were localized on $5 \mathrm{~d}^{1}$ impurity levels, and then formed a narrow impurity band when $x$ increased. These electrons interact with the localized spins of $\mathrm{Eu}^{2+}$ ions, giving a RKKY-type interaction. As long as $x$ remains small, and consequently as long as the dilution of moment carriers is negligible, this interaction, which has a ferromagnetic nature, tends to reinforce the coupling between $\mathrm{Eu}^{2+}$ ions. A consequence is the remarkable increase of the paramagnetic Curie temperature (Fig. 15).

For compositions corresponding to $0.05<\mathrm{x}<0.33$, there seems to be a noticeable difference between $T_{C}$ and $\left|\theta_{p}\right|$, indicating that long-range antiferromagnetic interactions compete with ferromagnetic interactions.

Another increase of $\mathrm{x}(0.33 \leq \mathrm{x} \leq 0.75)$ involves an increase of the average distance between $\mathrm{Eu}^{2+}$ ions; the RKKY interaction then becomes highly antiferromagnetic, which gives a negative paramagnetic Curie temperature; the long-range antiferromagnetic interactions become dominant.

For $x>0.75$, the dilution of the magnetic moments in the lanthanum hexaborides lattice is such that the material is paramagnetic at all temperatures.

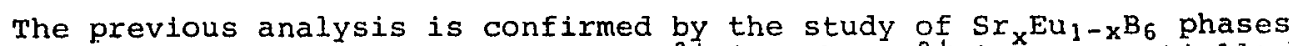
for $\mathrm{x} \leq 0.2$ : the substitution of $\mathrm{Eu}^{2+}$ ions by $\mathrm{Sx}^{2+}$ ions essentially creates a dilution of moment carriers. Even for quite a small dilution, the paramagnetic Curie temperature slightly decreases when $x$ increases. This result is consistent with the diminution of the paramagnetic Curie temperature with $x$, observed for $E u_{x} Y_{1-x} B_{6}$ phases (KRAUSE and SIENKO, 1973). 


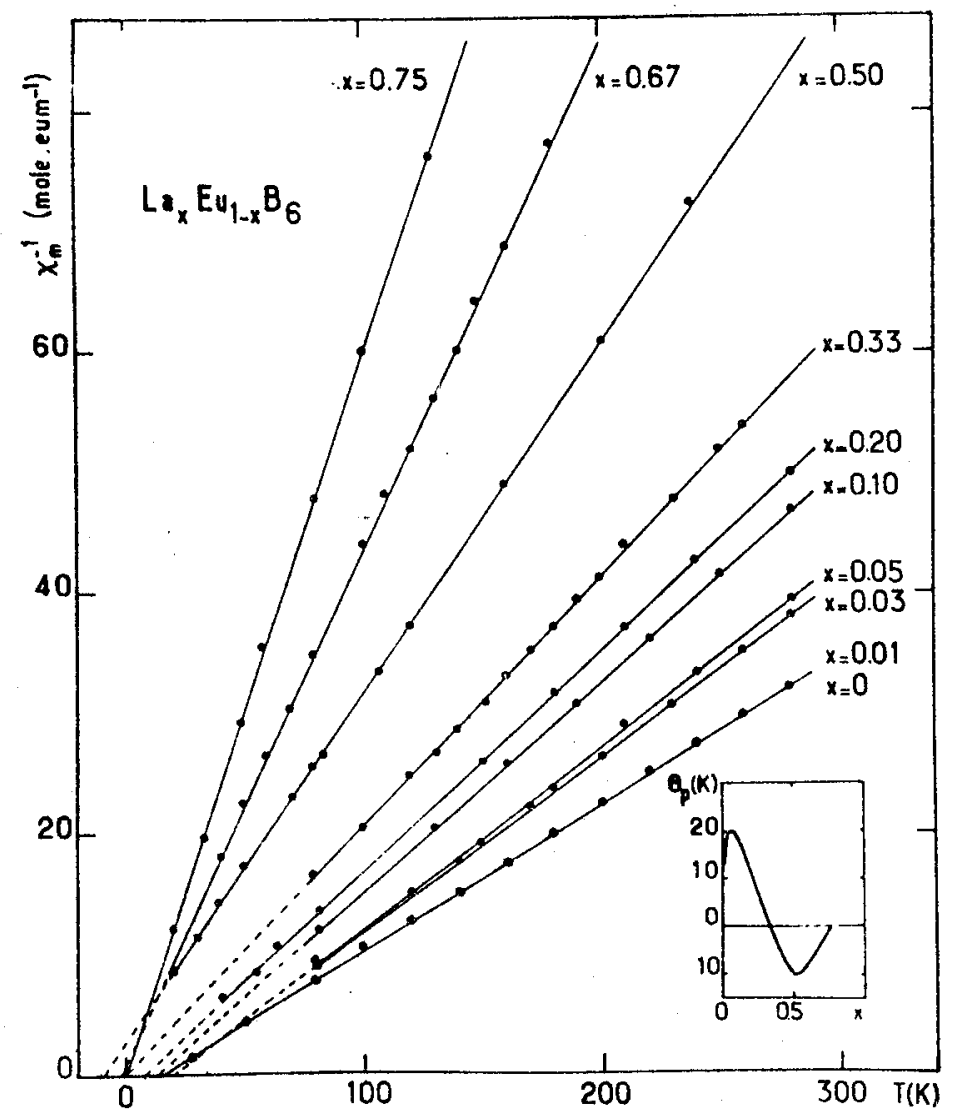

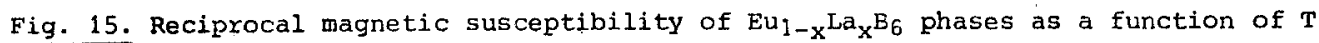
and paramagnetic Curie temperature as a function of $\mathrm{x}$

Samarium Hexaboride

All the magnetic data show that at high temperatures the magnetic susceptibility is intermediate to those corresponding to $4 \mathrm{f}^{6}$ and $4 \mathrm{f}^{5} 5 \mathrm{~d}^{1}$ configurations (MENTH et al., 1969; FALICOV and KIMBALL, 1969; MERCURIO, 1974).

The absence of magnetic order is in agreement with the simultaneous presence of both $\mathrm{Sm}^{2+}$ configurations: $4 \mathrm{f}^{6} 5 \mathrm{~d}^{0}$ and $4 \mathrm{f}^{5} 5 \mathrm{~d}^{1}$ : the shape of the $x^{-1}=f(T)$ curve shows that at low temperatures strong correlations occur in the localized $5 d^{1}$ levels (Fig. 16).

\section{b) Tetraborides}

The tetraboride unit cell contains 4 metal atoms and 16 boron atoms: 12 of them belong to two octahedra and the other 4 are bound by $\mathbf{s p}^{2}-$ type bonds. For stability each octahedron requires 20 electrons per $\left(\mathrm{MB}_{4}\right)$, group ( 14 for internal bonding, 6 for external bonding) and each op ${ }^{2}$-type bond requires 4 electrons, 1.e. a total of 56 electrons. Since 16 boron atoms provide only 48 electrons, an electron transfer from the motal sublattion 40 tho boron one is necessary to ensure the

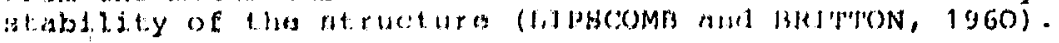




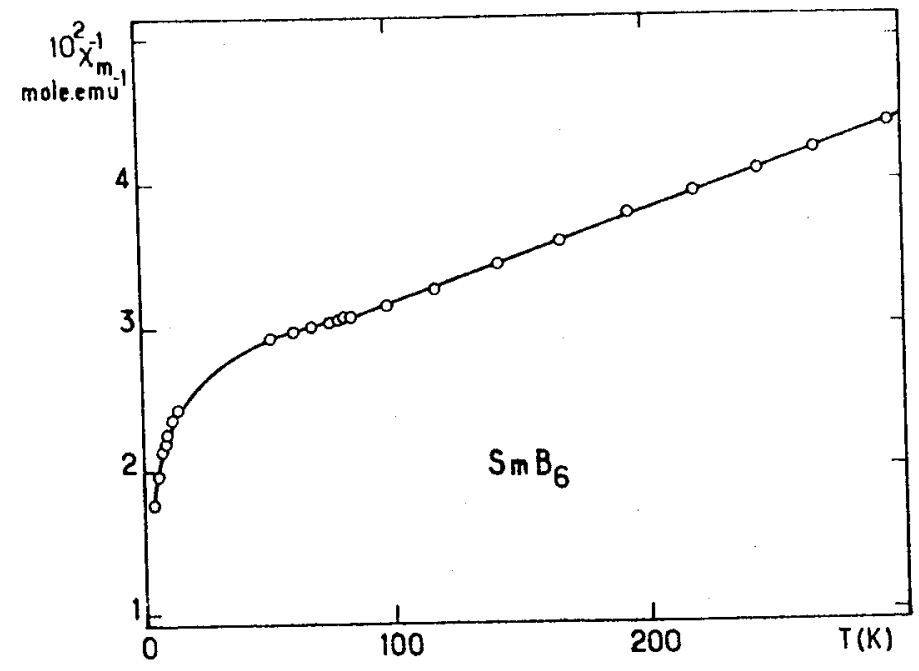

Fig. 16. Reciprocal magnetic susceptibility of $\mathrm{SmB}_{6}$ as a function of temperature

Unlike the situation for hexaborides, there have been hardly any publications to date on the physical properties of tetraborides.

a) Transport Properties

Only the electrical properties of $\mathrm{YB}_{4}, \mathrm{ThB}_{4}$ and $\mathrm{SmB}_{4}$ have been studied (JOHNSON and DAANE, 1963; AUSKERN and ARONSON, 1968; STURGEON, 1973): (JOHNSON and DAANE, with a metallic character. The number of conduction electrons per metal atom, deduced from Hall effect measurements, is 2 for $\mathrm{ThB}_{4}$, but only 0.2 for $\mathrm{YB}_{4}$. This result seems, in the case of yttrium, to require an oxidation state close to +II a localization at the bottom of the conduction band of the same type as that observed for $\mathrm{SmB}_{6}$; a magnetic investigation could corroborate this supposition.

B) Magnetic Properties

Tetraborides of Non-Magnetic Ions $\left(\mathrm{Y}^{3+}, \mathrm{La}^{3+}, \mathrm{Th}^{4+}\right)$

$\mathrm{YB}_{4}$ and $\mathrm{LaB}_{4}$ are diamagnetic, whereas $\mathrm{ThB}_{4}$ is Pauli paramagnetic (JOHNSON and DAANE, 1963; AUSKERN and ARONSON, 1964).

Tetraborides of Magnetic Rare Earths

The $\mathrm{NaB}_{4}, \mathrm{SmB}_{4}, \mathrm{GdB}_{4}, \mathrm{TbB}_{4}, \mathrm{DyB}_{4}$, HoB 4 and $\mathrm{TmB}_{4}$ phases order antiferromagnetically at low temperatures; the probable presence of two oxidation states for cerium and ytterbium in $\mathrm{CeB}_{4}$ and $\mathrm{YbB}_{4}$ is probably the reason for their particular magnetic behavior (no Curie-Weiss-type behavior). Only $\mathrm{PrB}_{4}$ in the series of the rare-earth tetraborides is ferromagnetic (BUSCHOW and CREYGHTON, 1972). iust as for hexaborides, the magnetic properties of tetraborides may be interpretable on the basis of indirect RKKY interactions through conduction electrons.

However it is noteworthy that a shifting of the ordering temperature with composition has been observed in the $\mathrm{UB}_{4}-\mathrm{DY}_{4}$ and $\mathrm{UB}_{4}-\mathrm{ErB}_{4}$ systems (ALI-ZADE et al., 1972). GIORGI et al. (1974) seem to have recently found a ferromagnetic ordering around $14 \mathrm{~K}$ in the $\mathrm{Y}_{\mathrm{x}} \mathrm{V}_{1-\mathrm{x}} \mathrm{B}_{4}$ system for $0.62<x<0.70$. 


\section{Fields of Application}

The $\mathrm{CaB}_{6}$-type hexaborides are well known for their mechanical and refractory properties, such as high congruent melting points and hardnesses close to that of boron $\left(3000 \mathrm{~kg} / \mathrm{mm}^{2}\right)$. They are also characterized by a great resistance to stress deformation $\left(5.10^{4} \mathrm{~kg} / \mathrm{mm}^{2}\right)$. Hexaborides have a high modulus of elasticity and a high tensile strength, which suggests their use as reinforcing elements in composite materials, in the way that alumina or carbides are actually used.

Most hexaborides and especially $\mathrm{LaB}_{6}$ are very good electrical conductors at high temperatures; furthermore, they have excellent thermionic properties: not only is the electronic emission potential quite low $12.7 \mathrm{eV}$ for $\left(\mathrm{LB}_{6}\right)$, but cathodes made of lanthanum hexaboride make it possible to obtain high current densities, better than those of standard cathodes such as $\mathrm{W}, \mathrm{ThO}_{2}$ or activated BaO (BROERS, 1973).

This property, together with the high chemical inertia and their thermal stability, causes lanthanum hexaboride to be more and more often substituted for materials generally utilized in demontable electronic tubes with high current densities, e.g. in scanning electron microscopes, electronic masks, etc.

\section{References}

ALI-ZADE, N.Kh., RAMAZANZADE, M.G., CHEChERNIKOV, V.I., GUSEINOV, N.G., SLOVIANSKII, V.K.: Magnetic properties of $\mathrm{UB}_{4}-\mathrm{DYB}_{4}$ and $\mathrm{UB}_{4}-\mathrm{ErB}_{4}$, Uch. Zap. Azerb. Inst. Nefti Khim., 9(8), 54-56 (1972)

ALIARD, G.: Etude roentgenographique de quelques borures. Bul1. Soc. Chim. 51, 12131215 (1932)

ANDRIEUX, L.: Electrolyse d'oxydes métalliques dissous dans l'anhydride borique ou les borates fondus. Nouvelles méthodes de préparation du bore amorphe, des borures et de quelques métaux. Ann. Chim. 12, 423-507 (1929)

AUSKERN, A.B.. ARONSON, S.: Electrical properties of thorium borides. J. Chem. Phys. 49(1)，172-176 (1968)

BACHMAN, R., LEE, K.N., GEEALLE, T.H., MENTH, A.: Spin scattering and magnetic ordering in EuB $_{6}$. J. Appl. Phys. 41(3), 1431-1432 (1970)

BENOIT, M.R.: Etude paramagnétique des composés binaires. J. Chem. Phys. 52(2) $119-132(1955)$

BERTAUT, F., BLUM, P.: La structure des borures d'uranium. C.R. Acad. Sci. (Paris) 229. $666-667$ (1949)

BLOEMBEKGEN, N., ROWLAND, T.J.: Nuclear sein exchange in solias: Tl 203 and $\mathrm{Tl}^{205}$ magnetic resonance in thallium and thallic oxide. Phys. Rev. 97, 1679-1698 (1955)

BIJU, P., BERTAUT, F.: Contribution à l'étude des borures à teneux élevêe en bore. Acta Cryst. 7, 81-86 (1954)

BREWER, L., SAWYER, D.L. quoted by ZALKIN, A., TEMPLETON, D.H.: The crystal structure of $\mathrm{CeB}_{4}, \mathrm{ThB}_{4}$ and $\mathrm{UB}_{4}$. J. Chem. Phys. 18(3), 391 (1950)

BROERS, A.N.: High-solution thermiontc cathode scanning txansmission electron microscope. Appl. Phys. Lett. $22(11), 610-612$ (1973)

BUSCHOW, K.H., CREYGHTON, J.H.N.: Magnetic properties of rare earth tetraborides. J. Chem. Phys., $57(9), 3910-3914$ (1972)

COHEN, R; $\mathrm{L}_{i}$ : Hyperfine structure in EuB 6 and EuTe studied with the Mossbauer effect in Eulsi. Bul1. Amer. Phys. Soc. 13, 667 (1968)

COHEN, R.L., EIBSCHUTZ, M., WEST, K.W., BUEHLER, E.: Electronic configuration of $\operatorname{SmB}_{6}$. J. Appl. Phys. $41(3), 898-899$ (1970) 
COLES, B.R., GRIFFITHS, D.: Antiferromagnetic behavior of $\mathrm{GdB}_{6}$. Proc. Phys. Soc. (London) 77 (1), 213-215 (1961)

CUR'IS, B.J., GRAFFENBERGER, H.: The floating zone crystal growth of lanthanum hexaboride. Mat. Res. Bull. 1, 27-31 (15166)

DEACON, J.A., HISCOCKS, S.E.R.: On the growth and properties of single crystal LaB 4 J. Mat. Sci. $6,309-312$ (1971)

EBERHARDT, W.H., CRAWFORD, J.B., LIPSCOMB, W.N.: The valence structure of boron hydrides. J. Chem. Phys. 22, 989-1001 (1954)

EICK, H.A., GILLES, P.W.: Precise lattice parameters of selected rare earth tetraand hexaborides. J. Amer. Chem. Soc. 81, 5030-5032 (1959)

EICK, H.A., MULFORD, R.N.R.: Americium and neptunium borides. J. Inorg. Nucl. Chem. $31,371-375$ (1969)

ETOURNEAU, J.: Les hexaborures de type $\mathrm{CaB}_{6}$. Le système bore-thorium. Thèse de Doct. Sci. Phys. Univ. BORDEAUX I (1970)

ETOURNEAU, J., MERCURIO, J.P., NASLAIN, R.: Etude comparative de la stabilité thermique des hexaborures de terres rares. C.R. Acad. Sci. (Paris) 275, 273-276 (1972a)

ETOURNEAU, J., MERCURIO, J.P., NASLAIN, R., HAGENMULIER, P.: Structure électronique de quelques hexaborures de type $\mathrm{CaB}_{6}$. J. Solid state Chem. $2,332-342$ (1970)

ETOURNEAU, J., MERCURIO, J.P., NASLAIN, R., HAGENMULLER, P.: Etude comparative de la stabilité thermique des tétraborures de terres rares. C.R. Acad. Sci. (Paris) 274, 1688-1691 (1972b)

ETOURNEAU, J., NASLAIN, R., LaPIACA, S.: L'hexaborure de thorium non-stoechiométrique $\mathrm{Th}_{1-\mathrm{x}^{\mathrm{B}} 6}$. J. Less Common Metals, 24, 183-194 (1971)

FALICOV, L.M., KIMBALL, J.C.: Simple model for semiconductor-metal transitions: SmB $_{6}$ and transition-metal oxides. Phys. Rev. Lett. 22, 997-999 (1969)

FIsK, Z.: Magnetic interactions in rare earth borides. Ph. D. thesis, Univ. California (1969)

FISK, Z., COOPER, A.S., SCHMIDT, P.H., CASTELLANO, R.N.: Preparation and lattice parameters of the rare earth tetraborides. Mat. Res. Bull. 7, 285-288 (1972)

FIODMARK, S.: A solid state spd-MOLCAO treatment of cubic-octahedral caB 6 with variation of the orbital exponent. Ark. Fys. 18(4), 49-64. (1960)

GEBALLE, T.H., MATTHIAS, B.T., ANDRES, K., MAITA, J.P., COOPER, A.S., CORENZWITT, E.: Magnetic ordering in rare-earth hexaborides. Science 160, 1443-1444 (1968)

GEBALLE, T.H., MENTH, A., BUEHLER, E., HULL, G.W.: Properties of $\mathrm{SmB}_{6}$ doped with Eu and Gd. J. Appl. Phys. 41 (3), 904-905 (1970)

GIORGI, A.L., SZKLARZ, E.G., WHITE, R.W., HILL, H.H.: Evidence for ferromagnetism In alloys formed between $\mathrm{UB}_{4_{4}}$ and $\mathrm{YB}_{4}$. J. Less Common Metals 34, 348-351 (1974)

GCODENOUGH, J.B., MERCURIO, J.P., ETOURNEAU, J., NASLAIN, R., HAGENMULLER, P.: Mécanisme de conduction électrique dans les hexaborures d'europium et d'ytterbium. C.R. Acad. Sci. (Paris) 277, 1239-1242 (1973)

GSCHNEIDNER, K.A., Jr.: Rare Earth Alloys pp. 116-130. Princeton: D. Van Nostrand Co, Inc. 1961

HACKER, H., Jr., SHIMADA, Y., CHUNG, K.S.: Magnetic properties of $\mathrm{CeB}_{6}, \mathrm{PrB}_{6}, \mathrm{EuB}_{6}$ and $\mathrm{GdB}_{6}$. Phys. Stat. So1. $\underline{4}, 459-465$ (1971)

JOHNSON, R.W., DAANE, A.H.: The lanthanum - boron system. J. Phys. Chem. 65, 909-915 (1961)

JOHNSON, R.W., DAANE, A.H.: Electron requixements of bonds in metal borides. J. Chem. Phys. 38, 425-432 (1963)

KASUYA, T.: A theroy of metallic ferro- antiferromagnetism on Zener's model. Prog. Theoret. Pliys. 16(1), 45-57 (1956)

KLOTZ, H.: Chemischer transport von Lanthanhexaborid. Naturwiss. 52, 451-452 (1965)

KRAUSE, J.L., SIENKO, M.J.: Long-range ordering in magnetically diluted europium hexaboride. J. Solid state Chem. 6, 590-594 (1973)

LAFFERIY, J.M.: Borlde cathodes J. Appl. Phys. 22 (3) 299-309 (1951)

I.EE, K.N., BACHMANN, R., GE3ALIE, T.H., MAITA, J.P.: Magnetic ordering in PrB 6 . Phys. Rev. B2(11), 4580-1585 (1970)

LEE, K.N., BELL, B.: Exchange interactions and fluctuations in CeB 6 . Phys. Rev. B $6(3), 1032-1040(1972)$

IIPSCOMB, W.N., BRITTON, D.: Valence structure of the higher borides. J. Chem. Phys. $33,275-280(1960)$ 
LONGUET-HIGGINS, H.C., ROBERTS, M. de V.: The electronic structure of the higher borides $\mathrm{MB}_{6}$ : Proc. Roy. Soc. 224A, 336-347 (1954)

MCDONALD, B.J., STUART, W.I.: Crystal structures of some plutonium borides, Acta Cryst. 13, 447-452 (1960)

MENTH, A., BUEHLER, E., GEBALLE, T.H.: Magnetic and semiconducting properties of $\mathrm{SmB}_{6}$. Phys. Rev. Lett. 22, 295-297 (1969)

MERCURIO, J.P.: Synthèse, stabilité thermique et proprítés électriques et magnétiques des hexaborures de terres raxes. Thèse Doct. Sci. Phys. Univ. BORdEAuX I. (1974)

MERCURIO, J.P., ETOURNEAU, J., NASLAIN, R., HAGENMULLER, P., GOODENOUGH, J.B.: Etude comparée des propriétés électriques des hexaborures d'europium et d'ytterbium. Mat. Res. Bull., 8, 837-844 (1973)

MERCURIO, J.P. ETOURNEAU, J., NASLAIN, R., HAGENMULLER, P., GOODENOUGH, J.B.: Propriétés électriques et magnétiques des solutions solides $\mathrm{La}_{\mathrm{x}} \mathrm{Eu}_{1-\mathrm{x}^{\mathrm{B}} 6}$. J. Solid
State Chem. 9, 37-47 (1974)

MOISSAN, H., WILLIAMS, P.: Sur la préparation et les propriétés des borures de calcium, de strontium et de baryum. C.R. Acad. Sci. (Paris) 125, 629-634 (1897)

NASLAIN, R., ETOURneAu, J.: L'hexaborure de potassium. C.R. Acad. Sci. (Paris) 263,

I $484-487,(1966)$

NASIAIN, R., GUETTE, A., BARRET, M.: Sur le diborure et le tétxaborure de magnésium. Considérations cristallochimiques sur les tētraborures. J. Solid State Chem. $\underline{8}$,
$68-85$ (1973)

NICKERSON, J.C., WHITE, R.M., LEE, K.N., BACHMANN, R., GEBALLE, T.H., HULL, G.W.: Physical properties of $\mathrm{SinB}_{6}$. Phys. Rev. B3(6), 2030-2042 (1971) NIEMYSKI, T., KIERZEK-PECOLD, E.: Crystali ization of lanthanum hexaboride. J. Cryst.
Growth 3-4, 162-165 (1968)

NIIHARA, $K_{.}$: The preparation and non-stoichiometry of samarium hexaboride. Bull. Chem. Soc. Japan 44, 963-967 (1971)

PADERNO, Yu.B., GORYACHEV, Yu.M., GARF, E.S.: Polyborides, their structure and properties. Electron Techn. 3(1/2), 175-183 (1970)

PADERINO, Yu.B., NOVIKOV, V.I., GARF, E.S.: Poroshkovaya Met. Akad. Nauk Ukr. SSr., $11(83), 70(1969)$

PADERNO, Yu.B., POKRZYWNICKI, S.: Magnetic properties of some heavy rare earth tetraborides. Sov. Phys. Solid State 24, K11-12 (1967)

PADERNO, Yu.B., POKRZYWNICKI, S., STALINSKI, 8.: Magnetic properties of some rare earth hexaborides. Sov. Phys. Solid State 24, K73-76 (1967) PAULING, L., WEINBAUM, S.: The structure of calcium boride CaB 6 . Z. Kristallogr.
187, 181-182 (1934)

POST, B., MOSKOWITZ, D., GLASER, F.W.: Borides of some rare-earth metals. J. Amer. Chem. SOC. 78, 1800-1802 (1956)

RABENAU, A., KAUER, E., KLOTZ, H.: Sur l'hexaborure de lanthane LaB 6 in: Propriétés the modynamiques, physiques et structurales des dérivés semi-métalliques, Proc. Int. Symp. CNRS, ORSAY, Sept. 28-Oct.1, 495-498 (1967)

RUDERMAN, M.A., KTTTEL, C.: Indirect exchange coupling of nuclear magnetic moments by conduction electrons. Phys. Rev. 96, 99-102 (1954)

SAMSONOV, G.V., PADERNO, YU.B., FOMENKO, V.S.: Hexaborides of rare earth metals. Poroshkovaya Met. Akad. Nauk Ukr. SSR 6 (18), 24-31 (1963)

SCHWETZ, K. LIPP, A.: Homogeneity region of the europium hexaboride phase: J. Less Common Metals 33, 295-303 (1973)

SHANNON, R.D., PREWITT, C.T.: Effective ionic radii in oxides and fluorides. Acta Cryst., 25, 925-928 (1969)

SPEAR, K.E.: Phase equilibria and related properties of the dysprosium boron-system. In: Boron, preparation, structure and properties. Ed. Science, (Moscow), 207-215,
1974 1974

STURGEON, G.D.: Personal communication (1973)

STURGEON, G.D., MERCURIO, J.P., ETOURNEAU, J., HAGENMUILER, P.: Single crystals of $S_{m B}$ for conductivity and other measurements. Mat. Res. Bull. 9, 117-120 (1974)

STACKEI,BERG, M. Von, NEUMANN, F.: Die Kristallstruktir der Boride der Zusammensetzung

YAJIMA, S.. NIIHARA, K.: The non stoichiometry of rare earth hexaborides. 9th Rareearth Res. Conf. Blacksburg, Virginja, October 10-14 (1971) 